NBER WORKING PAPER SERIES

INTERNATIONAL EFFECTS OF TAX REFORMS

Jacob A. Frenkel

Assaf Razin

Working Paper No. 2873

NATIONAL BUREAU OF ECONOMIC RESEARCH

1050 Massachusetts Avenue

Cambridge, MA 02138

March 1989

We are indebted to Guillermo Calvo, Martin Feldstein, Elhanan Helpman, and. Jonathan Ostry for helpful comments and suggestions. This paper was written while Assaf Razin was a visiting scholar in the Research Department of the International Monetary Fund. This paper is part of NBER's research program in International Studies. Any opinions expressed are those of the authors not those of the National Bureau of Economic Research. 
NBER Working Paper \#2873

March 1989

\section{INTERNATIONAL EFFECTS OF TAX REFORMS}

\section{ABSTRACT}

This paper highlights the significance of open-economy considerations in the analysis of tax reforms. It focuses on domestic and international consequences of revenue-neutral conversions between income and value-added tax systems.

The principal conclusion of this investigation is that the direction of changes in the world rate of interest, the domestic tax-adjusted rate of interest, domestic and foreign investment, growth rates of consumption, and other key macroeconomic variables consequent on revenue-neutral tax reforms depend on whether the country adopting the tax reform runs a surplus or a deficit in the current account of its balance of payments. For example, a conversion from an income to a value-added tax system lowers the world rate of interest if the country adopting the reform runs a surplus in the current account of its balance of payments, but raises the world rate of interest if its current account is in a deficit.

The paper also examines the implications of such reforms in the presence of direct foreign investment and considers alternative specifications of tax treatments, one based on the source of income, and the other on the country of residence of the taxpayer. It demonstrates the robustness of the key propositions to these alternatives.

Jacob A. Frenke l Research Department International Monetary Fund 70019 th Street, NW Washington, DC 20431
Assaf Razin

Department of Economics Te1-Aviv University

Ramat-Aviv, Tel-Aviv 69978 ISRAEL 


\section{Introduction}

This paper deals with key international effects of tax reforms. Recent years have witnessed a growing interest in the introduction of such reforms. In many countries, the impetus to tax restructuring has come from the realization that the prevailing tax structures have introduced significant distortions into the saving and investinent decisions of household and flrms as well as into the decisions governing labor supply and demand. Tax reforms have incorporated a wide variety of proposals. A key feature of many of them is a proposed change in the composition of the tax base from income to consumption (or, equivalently, value-added tax under which investment and exports are exempt). The move towards value-added taxes (VAT) is now widespread and has been stimulated especially by the decision in the United Kingdom in 1979 to nearly double its VAT rate. Such a move has subsequently been put on the tax-reform agenda of other countries, including Australia, Canada, Greece, Japan, New Zealand, Portugal, Spain, and Turkey. I'

Much of the recent research of the economic consequences of tax reforms has been conducted in a closed-economy framework. 2 f It has abstracted therefore from important issues that arise in the incerdependent world economy. The increased integration of the world

1/ For a recent comparative analysis of the tax systems in several Eurropean countries, Canada and Japan, see Pechman (1987), and for a discussion of recent tax reforms see Tanzi (1987).

2/ Examples are Boskin (1978), Bradford (1984, 1986), Hall and Rabushka (1983), and King (1987). Examples of dynamic generalequilibrium models of a closed economy are contained in Brock and Turnovsky (1981) and Judd (1987a, 1987b). A comprehensive closedeconomy treatment is contained in Auerbach and Kotlikoff (1987). 
capital market has raised the extent by which tax policies in individual countries influence, and are influenced by, the rest of the world. To capture this feature and to fill a gap in the analytical Iiterature we propose an analytical framework extending the closed-economy analysis to a two-country model of the world economy in which capital markets are fully integrated. In this framework the world capital market provides the key channel through which the effects of tax policies undertaken in one country are transmitted to the rest of the world.

The open-economy perspective to the analysis of tax policies enables a treatment of questions and issues that could not have been dealt with in a closed-economy framework. Furthermore, open-economy considerations lead to significant modifications of propositions derived previously in a closed economy model. The key result of this paper is that the domestic and international consequences of tax reforms characterized by revenue-neutral conversions from income to consumption taxes depend critically on the trade-balance position. The fundamental determinants of this trade-balance position include inter-country differences in saving propensities, investment opportunities, and the pattern of government spending. In this context, we distinguish between a pro-borrowing tax reform as the one which stimulates current external borrowing (national dissaving) and a pro-lending tax reform as the one which stimulates current external lending (national saving). We show that if the country which introduces the revenue-neutral conversion between income and consumption taxes runs a trade balance surplus, then the reform is pro-lending. Under such circumstances, tax conversions of 
this type lower the world rate of interest. On the other hand, if the economy runs a trade-balance deficit, then such tax reforms are proborrowing and result in a higher world rate of interest. This result is used to determine the implications of tax reforms for domestic and foreign capital formation and growth rates of consumption.

In section II we specify the tax structure and develop the analytical framework suitable for the analysis of tax conversions. In section III we present a simple general equilibrium model of a twocountry world economy and develop the diagrammatic apparatus that is used in the subsequent analysis. Section IV which contains the main results of the paper is devoted to the analysis of revenue-neutral tax reforms involving income and consumption tax systems. Section $V$ extends the analysis to a world economy in which foreign direct investment is allowed for. Section VI contains concluding remarks. The three appendices following the main text deal, respectively, with variable labor supply, alternative assumptions concerning the expensing of investment under the income-tax system, and with the consequences of an international-borrowing tax.

\section{The Tax Structure}

To set the stage for the analysis of revenue-neutral tax reform, we choose to represent the tax system by four types of taxes: consumption tax, income tax, international borrowing tax, and interest earnings tax. These four types of taxes are chosen because of their unique effects on spending and saving behavior. We specify the various taxes 
in their pure form in order to highlight the key economic mechanisms governing their effects. We thus abstract from many details present in actual tax systems.

Consider a two-period model of a nonmonetary open economy producing and consuming one aggregate tradable good. The aggregation of goods into a single aggregate commodity and the abstraction from money are done in order to focus attention on intertemporal trade, that is, on international borrowing and lending. The economy is assumed to be endowed with an initial sequence of endowments, $\bar{Y}_{O}$ and $\bar{Y}_{I}$ where the subscripts zero and one designate the corresponding periods. The initial endowment may be consumed or, alternatively, it may be invested in intertemporal production process. Such an investment process modifies the intertemporal pattern of available outputs (GDP). Formaily, output in period one, $Y_{1}$, is Iinked to the initial endowments through $Y_{I}=\bar{Y}_{I}+F\left(I_{0}\right)$ where $I_{0}$ denotes investment in period zero. The function $F\left(I_{0}\right)$, which transforms current investment into future output, exhibits positive, and diminishing returns. To simplify, we assume that labor supply is inelastic. I/

In this two-period model, the private sector's budget constraints are:

$$
\begin{aligned}
& \left(I+\tau_{c 0}\right) C_{0}=\left(1-\tau_{y 0}\right)\left(\bar{Y}_{0}-I_{0}\right)-\left(I-\tau_{r O}\right) r_{-I} B_{-I}^{p}+\left(I-\tau_{b 0}\right)\left(B_{0}^{P}-B_{-I}^{p}\right) \\
& \left(I+\tau_{c I}\right) C_{I}=\left(I-\tau_{y I}\right)\left(\bar{Y}_{I}+F\left(I_{0}\right)\right)-\left(I-\tau_{r I}\right) r_{0} B_{0}^{p}-\left(I-\tau_{b I}\right) B_{0}^{P}
\end{aligned}
$$

1/ This assumption which is relaxed in Appendix I does not alter the qualitative results. 
In equations $(1)-(2), C_{0}$ and $C_{1}$ denote first and second-period consumption, $B_{t}^{p}(t=-1,0)$ denotes period $t$ borrowing (which could be positive or negative), $I_{0}$ measures the losses of firms (negative dividends) corresponding to initial investment, $F\left(I_{0}\right)$ measures second period dividends, $r_{t}(t=-1,0)$ denotes the world rate of interest in period $t$, and $\tau_{c t}$, ' $\tau_{t}$ ' ' $r t$, and $\tau_{b t}(t=0,1)$ denote, respectively, the ad-valorem tax rates in period $t$ on consumption, income, interest earnings, and new international borrowing. In this two-period model, the solvency requirement ensures that in the second period the private sector settles all debt commitments and does not incur new debt.

In equation ( 1 ), the consumption tax base is $C_{0}$ and its coefficient indicates that the unit cost of consumption is one plus the corresponding ad-valorem consumption tax. This consumption tax is equivalent to a value-added tax system (VAT) under which investment and exports are exempt. The income tax base is $\left(\bar{Y}_{0}-I_{0}\right)$ and its coefficient is one minus the corresponding ad-valorem income tax, reflecting taxes on income from labor and existing capital $\left(\bar{Y}_{0}\right)$ and a tax rebate on negative income from current investment. This tax is a cash-flow income tax with full expensing of investment. 1/ The interest earnings tax base is $r_{-1} B_{-1}^{b}$ and its coefficient is one minus the ad-valorem interest earnings tax. The international borrowing tax base $\left(B_{0}^{P_{-}} B_{-1}^{b}\right)$, corresponds to the amount of new private sector net borrowing as

1/ This treatment of expensing of capital outlays is modified in Appendix II in which we consider the other extreme case under which capital outlays are expensed in the final period. 
reflected in changes in its external debt position. Its coefficient is one minus the ad-valorem international borrowing tax. I' An analogous interpretation applies to the second budget constraint in equation (2). We note that in the second ( $f$ inal) period there is negat 1ve new net borrowing (since past debt is repald and no new debt is issued); therefore, the term $\tau_{b I}{ }^{B}{ }_{0}^{p}$ corresponds to a tax rebate.

As is evident from the formulation of equations (1)-(2), the four taxes are linked through an equivalence relation. This equivalency implies that the effect on the real equilibrium of any combination of the four taxes can be duplicated by a pollcy consisting of any three of them. Our formulation reveals that, although in a closed-economy context consumption and income taxes are equivalent, they do not remain equivalent if the economy is open to International trade, in which case an international borrowing tax must be added. The equivalence relation Implies that the entire spectrum of tax systems can be spanned by these four types of taxes. This property provides the rationale for our cholce of the specific tax structure used in this paper.

With these taxes, the perlodic budget constralnts of the government are

$$
G_{0}=B_{0}^{B}+\tau_{c 0} C_{0}+\tau_{y 0}\left(\bar{Y}_{0}-I_{0}\right)-\tau_{r_{0}} r_{-1} B_{-1}^{p}+\tau_{b 0}\left(B_{0}^{P}-B_{-1}^{p}\right)-\left(1+r_{-1}\right) B_{-1}^{B}
$$

(4) $\quad G_{1}=\tau_{c l} C_{1}+\tau_{y l}\left(\bar{Y}_{I}+F\left(I_{0}\right)\right)-\tau_{r l} r_{0} B_{0}^{p}-\tau_{b 1} B_{0}^{p}-\left(1+r_{0}\right) B_{0}^{B}$

If As is evident, if $\tau_{r t}=\tau_{b t}$, then the tax base for international borrowing tax is broadened to include debt service, whlle if $\tau_{\mathrm{rt}}=\tau_{\mathrm{yt}}$ then the tax base for income tax 1 s broadened to include interest earnings. 
where $C_{t}(t=0,1)$ denotes goverment purchases in period $t$ and where $B_{t}^{g}$ $(t=-1,0)$ denotes government borrowing in period $t$. Analogously to the private sector, solvency requires that, in the second period, the government settles all debt commitments and does not incur new debt. In this formulation we have implicitely assumed that aside from domestically imposed taxes, the private-sector and the governiment can borrow at the same rate of interest in the world capital market. We also note that, in conformity with the national income identities, in each period, the difference between aggregate absorption and GNP equals the net accumulation of external debt (the sum of private and public-sector debts); this can be verifled by adding, for each period, the private sector's and the government budget constraints. 1/

$1 /$ It is noteworthy that according to the specification in equations (1) through (4), the government does not sell bonds to the domestic private sector. This simplifying assumption does not affect the analysis. To verify this point, let $-\mathrm{B}^{\mathrm{p}}$ and $-\mathrm{B}^{\mathrm{g}}$ denote forelgn bonds purchased by the domestic private sector and the domestic government, respectively, and let $\mathrm{A}^{\mathrm{B}}$ denote domestic-government bonds purchased by the domestic private sector. In the presence of taxes on interest earnings and on international borrowing, arbitrage between government bonds and foreign bonds implies that

$$
\begin{gathered}
\left(\left(1-\tau_{r_{1}}\right) r_{0}+\left(1-\tau_{b 1}\right)\right) /\left(1-\tau_{b 0}\right)=1+r^{8}, \text { and } \\
0 \\
\left(\left(1-\tau_{r_{0}}\right) r_{-1}+\left(1-\tau_{b 0}\right)\right) /\left(1-\tau_{b},-1\right)=1+r^{8}, \text { where } r_{t}^{8}(t=-1,0)
\end{gathered}
$$

denotes the market rate of interest on government bonds sold to the domestic private sector. These considerations can be incorporated into the various budget constraints by subtracting the term $\left[A_{0}^{B_{-}}\left(1+r \underline{g}_{1}\right) A g_{1}\right]$ from the right-hand side of equation (1) and adding it to the right-hand side of equation (2) and subtracting it from the right-hand side of equation (4). The reader may verify that these modifications do not affect the results, and for ease of exposition, we henceforth set $A_{-1}^{B}=$ $A_{0}^{B}=0$. 
The private sector seeks to maximize life-time utility subject to the consolidated life-time budget constraint, obtained from the periodic budget constraints. Accordingly, adding equation (2), multiplied by $\left(1-\tau_{b 0}\right) /\left(\left(1-\tau_{r l}\right) r_{0}+1-\tau_{b l}\right)$ to equation (1) and dividing the resulting equation by $\left(1+\tau_{c 0}\right)$ yields

$$
\begin{aligned}
C_{0}+\alpha_{c} C_{1}= & \frac{\left(1-\tau_{y 0}\right)\left(1-\tau_{b 0}\right)}{\left(1+\tau_{c 0}\right)}\left[\alpha_{I}\left(\bar{Y}_{1}+F\left(I_{0}\right)\right)+\left(\bar{Y}_{0}-I_{0}\right)\right] \\
& -\frac{\left(1-\tau_{r_{0}}\right) r_{-1}+\left(1-\tau_{b 0}\right)}{\left(1+\tau_{c 0}\right)} B_{-1}^{p}
\end{aligned}
$$

where

$$
\begin{aligned}
& \alpha_{c}=\frac{\left(1+\tau_{c l}\right)\left(1-\tau_{b 0}\right)}{\left(1+\tau_{c 0}\right)\left(\left(1-\tau_{r l}\right) r_{0}+\left(1-\tau_{b l}\right)\right)} \\
& \alpha_{I}=\frac{\left(1-\tau_{y l}\right)\left(1-\tau_{b 0}\right)}{\left(1-\tau_{y 0}\right)\left(\left(1-\tau_{r l}\right) r_{0}+\left(1-\tau_{b l}\right)\right)} .
\end{aligned}
$$

Equation (5) is the consolidated private-sector budget constraint which incorporates the role of taxes. The key point to emphasize is that the discount factors applicable to the quantities pertaining to the future period (period one) are the tax-inclusive discount factors. These are the effective discount factors relevant for private-sector decisions. Accordingly, $\alpha_{c}$ measures the effective intertemporal price of $\mathrm{C}_{1}$ in terms of $\mathrm{C}_{0}$. This price reflects the prevailing tax structure. It is governed by the time profiles of the consumption tax (reflected by the ratio $\left(1+\tau_{c l}\right) /\left(1+\tau_{c 0}\right)$ ) and of the interest earnings and international borrowing taxes reflected by the ratio 
$\left(1-\tau_{b 0}\right) /\left(\left(1-\tau_{r l}\right) r_{0}+\left(1-\tau_{b l}\right)\right)$. Analogously, $\alpha_{I}$ measures the effective intertemporal price of future output in terms of current output from the perspective of the firm, thus it corresponds to Tobin's $Q$ governing investment decisions. ${ }^{\prime}$ This effective discount factor reflects the time pattern of the taxes on income, international borrowing, and interest earnings. In comparing the two effective discount factors $\alpha_{C}$ and $\alpha_{I}$ we note that $\alpha_{c}$ does not depend on the taxes on income, and $\alpha_{I}$ does not depend on the taxes on consumption. $\underline{2}$ Finally, we note that if the time profile of any given tax is flat (so that $\tau_{c 0}=\tau_{c l}$ or $\tau_{y 0}=\tau_{y l}$ or $\tau_{b 0}=\left(\tau_{b l}+r_{0} \tau_{r l}\right) /\left(1+r_{0}\right)$, then this tax is nondistortionary and its impact is similar to that of a lump-sum tax. In this formulation, the "flatness" of the International borrowing tax is expressed in terms of present value, adjusted for the tax on the debt service. $\underline{3}^{\prime}$ This convenient property which will be used in the

1/ It is shown in Appendix I that with variable labor supply, the same effective discount factor governs the intertemporal allocation of labor supply. It is also shown in Appendix. I that in the absence of full expensing of investment outlays the effective discount factor governing investment is modified though the corresponding discount factor governing labor supply remains intact.

$2 /$ It is relevant to note that this dependence of the effective discount factors on the time profiles of the various taxes reflects the non-R1cardian feature of the model. Obviously a budget deficit arising from a current tax cut (for a given path of government spending) must be followed by a future tax hike ( 1 n order to assure government solvency). In the present formulation, this change in the time profile of taxes alters the effective discount factors. This provides for the principal channel through which budget deficits affect the intertemporal allocation of consumption and investment. For an analysis of budget deficits In this context, see Frenkel and Razin (1986).

3/ Alternatively, the "flatness" means that the initial-period international-borrowing tax rate is a welghted average of the subsequentperiod international borrowing and interest earnings tax rates, where the weights are $1 /\left(1+r_{0}\right)$ and $r_{0} /\left(1+r_{0}\right)$, respectively. 
subsequent analysis underlies our choice of the cash-flow formulation of the income tax.

\section{World Equilibrium}

In this section we develop a simple general-equilibrium model of a two-country world economy. To facilitate the exposition we assume that Initially all taxes, government spending, and the historically given initial debt comittments are all zero. Thus, in terms of equation (5), the domestic discount factors governing consumption and investment decisions, $\alpha_{c}$ and $\alpha_{I}$, respectively are initially equal to the world discount factor $\alpha=1 /\left(1+r_{0}\right)$. These assumptions imply that the discounted sum of the economy's trade balances must be zero. That is,

(6) $\left[\left(C_{0}+I_{0}\right)-\bar{Y}_{0}\right]+\frac{1}{1+r_{0}}\left[C_{1}-\left(\bar{Y}_{1}+F\left(I_{0}\right)\right)\right]=0$

It follows that under such circumstances, an initial trade balance deficit must be followed by a subsequent trade balance surplus and vice versa.

In what follows, we carry out the analysis by means of a simple diagrammatic apparatus. The initial equilibrium is portrayed in Figure 1 in which the upward sloping schedule, $s^{W}$, describes the ratio, $z$, of current to future world GDP net of investment, as an increasing function of the rate of interest. Formally, the world relative supply (evaluated at $r=r_{0}$ ) is

$$
z^{W}=\frac{\bar{Y}_{0}-I_{0}\left(r_{0}\right)+\bar{Y}_{0}^{*}-I_{0}^{*}\left(r_{0}\right)}{\bar{Y}_{1}+F\left[I_{0}\left(r_{0}\right)\right]+\bar{Y}_{1}^{*}+F^{*}\left[I_{0}^{*}\left(r_{0}\right)\right]}
$$


FIGURE 1

\section{RELATIVE DEMANDS, RELATIVE SUPPLIES AND WORLD EQUILIBRIUM}

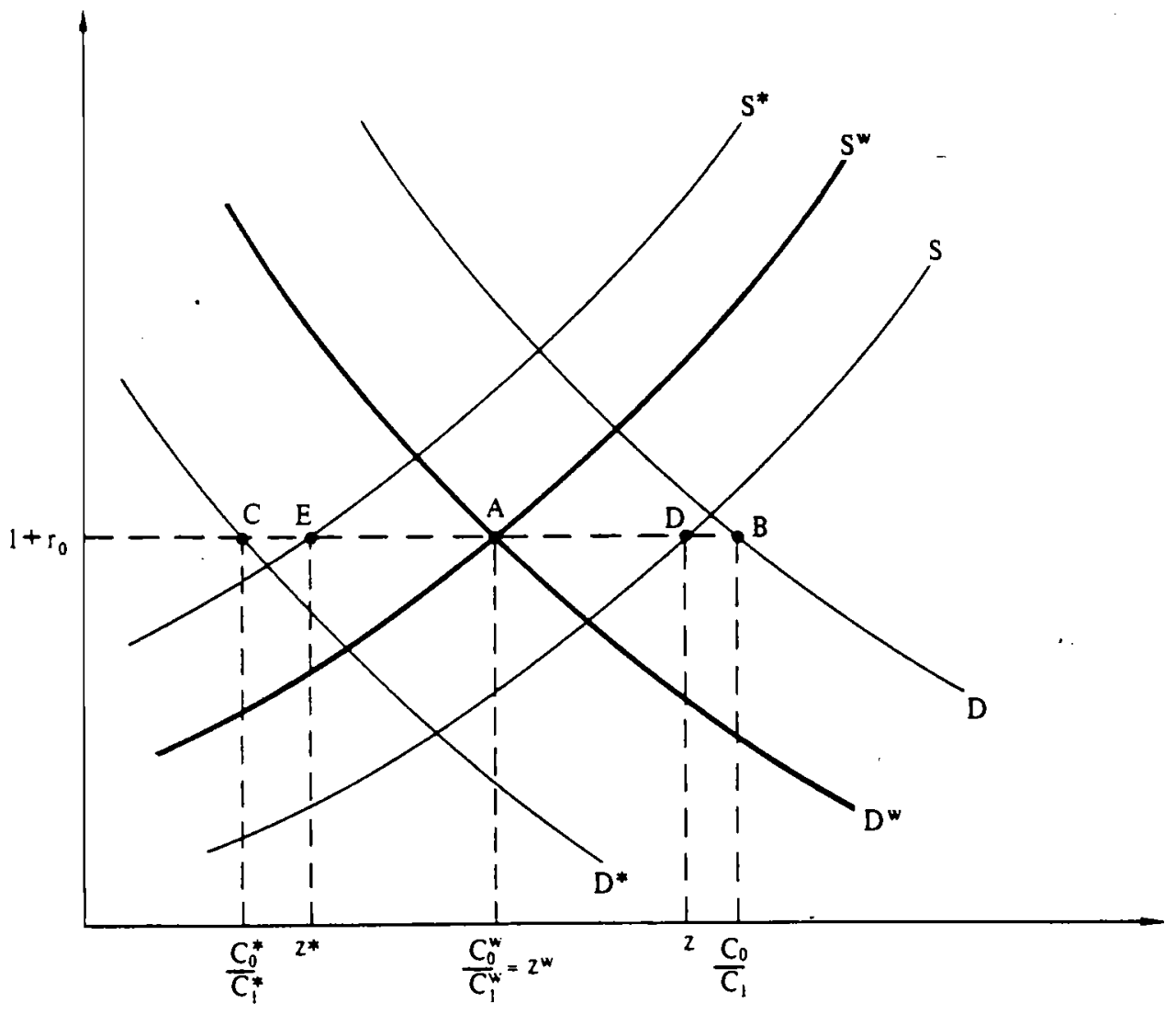


The positive dependence of $z$ on the rate of interest reflects the fact that investment falls when the rate of interest rises. The world relative supply schedule, $S^{W}$, is a welghted average of the donestic country's relative supply schedule, $S$ (where $S=\left[\bar{Y}_{0}-I_{0}(r)\right] /\left[\bar{Y}_{1}+F\left[I_{0}(r)\right]\right]$ ) and the foreign country's relative supply schedule, $S^{*}$, (where $S^{*}=$ $\left.\left[Y_{0}^{*}-I_{0}^{*}(r)\right] /\left[\bar{Y}_{1}^{*}+F^{*}\left[I_{0}^{*}(r)\right]\right)\right)$. Accordingly,

$$
\text { (8) } S^{W}=\mu_{s} S+\left(1-\mu_{s}\right) S^{*}
$$

where the domestic country's weight is

$$
\mu_{s}=\frac{\bar{Y}_{1}+F\left[I_{0}(r)\right]}{\bar{Y}_{1}+F\left[I_{0}(r)\right]+\bar{Y}_{1}^{*}+F^{*}\left[I_{0}^{*}(r)\right]}
$$

The downward sloping schedules in Figure 1 plot the desired ratio of current to future consumption as a decreasing function of the rate of interest. These schedules embody the simplifying assumption that the utility functions are homothetic. The domestic and foreign relative demands are denoted by $D$ and $D^{*}$, respectively, and their values at the point in which $C_{0} / C_{1}=C_{0}^{*} / C_{1}^{*}=1$ indicate, respectively one plus the subjective rates of time preference, $1+p$ and $1+p^{*} . \underline{1}$ The elasticities

1/ Our simplified model abstracts from durable consumption goods. Allowing for such goods would modify some of the details of the analysis. For example, in the special case of logarithmic utility functions, the durable consumption goods can be introduced into the model in a way that requires only a reinterpretation of the relative demand schedules. Accordingly, let the utility function be $\mathrm{U}\left(\mathrm{C}_{0}, \mathrm{C}_{1}\right)=\log \mathrm{C}_{0}+\delta \log \mathrm{C}_{1}$ where the $\delta=1 /(1+\rho)$ denotes the subjective discount factor, and $C_{t}(t=0,1)$ denotes the stock of consumer goods in period $t$. This stock is related to the flow of consumption purchases $x_{t}$ 
of the relative-demand schedules are the corresponding intertemporal elasticities of substitution in consumption. Analagously to the construction of the world relative supply, the world relative demand

$$
D^{w}=C_{0}^{w} / C_{1}^{w}=\left(C_{0}+C_{0}^{*}\right) /\left(C_{1}+C_{1}^{*}\right)
$$

is a welghted average of the two countries' relative demands, $D=C_{0} / C_{1}$ and $D^{*}=C_{0} / C_{1}^{*}$. Accordingly,

$$
\text { (10) } \quad D^{W}=\mu_{d} D+\left(1-\mu_{d}\right) D^{*}
$$

where the domestic country's weight is

$$
\mu_{d}=\frac{c_{1}}{c_{1}+c_{1}^{*}} .
$$

The initial equilibrium is exhibited by point $A$ in Figure 1. As shown, the world rate of interest is $r_{0}$ and the world consumption ratio (1ndlcating the reciprocal of the growth rate of world consumption) is $\mathrm{C}_{\mathrm{O}}^{\mathrm{W}} / \mathrm{C}_{1}^{\mathrm{W}}$. The domestic and foreign consumption ratios corresponding to this equilibrium are $C_{0} / C_{1}$ and $C_{0}^{*} / C_{1}^{*}$, as Indicated by points $B$ and $C$, respectively. We also note that the domestic and forelgn relative supplies associated with this equilibrium are $z$ and $z^{*}$ as indicated by points $D$ and $E$, respectively. As is evident, these levels of relative

(continued from page 11) through

$C_{t}=X_{t} C_{t-1}^{1-\phi}$ where $\phi$ denotes the rate of depreciation of the stock and $t=0,1$. In that case, it can be shown that the marginal rate of substitution between the flow of consumption purchases in the two perlods is $[(1+\delta(1-\phi)) / \delta]\left[x_{1} / x_{0}\right]$. With this modification, the horizontal axis in Figure 1 measures the ratio $x_{0} / X_{1}$ and at the point in which this ratio equals unity the value of the relative demand is $(1+\rho)+(1-\phi)$. Thus, in this case, the position of the relative demand schedules depend on both the subjective rates of time preference and the degree of durability. 
supplies are associated with the equilibrium levels of domestic and foreign investment. Finally, since point $B$ lies to the right of point $D$, while point $C$ lies to the left of point $E$, the domestlc economy runs an initial period trade balance deficit whlle the foreign economy runs a corresponding trade balance surplus. This pattern of trade imbalances is implied from the assumed zero level of the predetermined initial debt'position. As indicated by equation (6), this configuration of trade imbalances is reversed in the subsequent period. We also note that this pattern of trade imbalances implies that the equilibrium domestic relative demand weight, $\mu_{d}$, falls short of the corresponding relative supply weight, $\mu_{s} \underline{I}^{\prime}$

\section{Revenue-Neutral Tax Reforms}

In this section, we prepare the analytical groundwork suitable for the analysis of revenue-neutral tax reforms. Such reforms are characterized by a change in the composition of a given tax revenue among different tax bases. It is obtained through alterations in the various tax rates designed to keep total tax revenue in each period intact.

This specification ensures that the requirement of revenue neutrality is conceptually distinct from the government solvency constraint. If such a period-by-period neutrality requirement was not imposed then, as long as government outlays are fixed, the government solvency constraint would only necessitate that the various tax rates are adjusted so as to

If This follows from the fact that in equilibrium the denominators of $\mu_{s}$ and $\mu_{d}$ are equal to each other. Thus, if the domestic economy runs a trade surplus in the second period (so that $C_{1}<Y_{1}+F\left(I_{0}\right)$ ) then $\mu_{d}<\mu_{s}$. 
keep the discounted sum of government revenue intact. Under such circumstances, tax-rate changes result in periods with budget deficits being of set by corresponding budget surpluses (of equal present value) in other periods. $1 /$

We focus on the implications of tax policies on the saving-investment balance, on the world rate of interest and on other key macroeconomic variables in the world economy. To isolate the main fact ors governing the consequences of such revenue-neutral tax reforms, we consider a reform that replaces one tax system by another while malntalning all other taxes intact. The tax reform can be thought of as consisting of two components. First, it involves a permanent reduction of a prevailing tax and a permanent equiproportional rise of another tax. Second, it involves further adjustments in the newly introduced tax aimed at restoring the initial level of tax revenue in each period. Evidentiy under such circumstances the first component of the reform does not alter the effective discount factors governing intertemporal decisions concerning consumption, investment and labor supply. As a result the dynamic characteristics of the real equilibrium remain intact. However, with trade imbalances, this intertemporally-neutral change in the tax structure creates periodic governmental budgetary imbalances. To ensure revenue neutrality the second component of the reform introduces further tax adfustments. To simplify we henceforth assume that the historically given initial debt commitment as well as

$1 /$ For an analysis of the effects of budget deficits arising from intertemporal tax shifts, see Frenkel and Razin (1986). 
government spending are zero, and that initially all tax rates are also zero. Throughout the analys is we focus on tax reforms involving conversions between income and consumption tax systems. 1/

\section{Revenue-neutral conversion from income to consumption taxes}

Consider a revenue-neutral tax reform that substitutes a consumption-tax system for an income-tax system. The introduction of permanent consumption taxes at the rate $\tau_{c}$ accompanied by the equiproportional reduction in income taxes alter the periodic government tax revenue, $T_{t}$, by

$$
\begin{aligned}
& T_{0}=\tau_{c}\left(C_{0}-\bar{Y}_{0}+I_{0}\right) \\
& T_{1}=\tau_{c}\left(C_{1}-\bar{Y}_{1}-E\left(I_{0}\right)\right) .
\end{aligned}
$$

As formulated, the periodic tax revenue is the product of the ad-valorem consumption-tax rate and the economy's trade balance position. Since the discounted sum of the trade balances is zero (see equation (6)) it follows that the discounted sum of the tax revenues is also zero and thus government solvency remains intact. However, this tax shift is not revenue neutral if there are trade imbalances. As is evident from equation (12) this tax shift creates a current-period government budget surplus if the domestic economy runs a current-period trade-balance deficit and vice versa. Obviously, as indicated by equation (13) this pattern of budgetary and trade imbalances is reversed in the subsequent period. The second component of the tax reform aims at restoring revenue neutrality in each period. Since the econony has adopted a an international-borrowing tax system. 
consumption tax system, it is assumed that the restoration of revenue neutrality is achieved through appropriate further adjustments in the consumption tax rates.

Suppose that the domestic economy runs an initial-period tradebalance deficit. Under such circunstances the first component of the tax reform results in an initial-period government budget surplus and in a corresponding future-period deficit. To restore revenue neutrality the current-period consumption tax rate, $\tau_{c o}$, must be lowered while the corresponding future-period rate $\tau_{c 1}$, must be raised. This pattern of tax rates, breaks the flatness of the time profile of the consumption tax so that $\tau_{c o}<\tau_{c 1}$. The new configuration of the consumption tax rates raises $\alpha_{c}$--the effective discount factor applicable to consumption decisions--so that $\alpha_{c}=\left[\left(1+\tau_{c 1}\right) /\left(1+\tau_{c o}\right)\right] \alpha$ exceeds the world discount factor $\alpha=1 /\left(1+r_{0}\right)$. Since income taxes remain $f l a t$, the effective discount factor applicable to investment decisions remains intact, so that $\alpha_{I}=\alpha$.

Armed with this information we analyze in Figure 2 the effects of this tax reform. The initial equilibrium is portrayed by point $A$ at which the world rate of interest is $r_{0}$ (as in Figure 1). The rise in the effective discount factor applicable to consumption (that is, the reduction in the corresponding effective rate of interest) induces an intertemporal substitution in domestic demand towards current-period consumption. Thus, for each and every value of the world rate of Interest, the domestic (relative) demand schedule shifts to the right from $D$ to $D^{\prime}$. The proportional vertical displacement of the schedule equals the proportional tax-induced rise in the effective discount 
FIGURE 2

THE EFFECTS OF A REVENUE-NEUTRAL TAX SHIFT FROM INCOME TAXES TO CONSUMPTION TAXES WITH AN INITIAL-PERIOD DOMESTIC TRADE-BALANCE DEFICIT

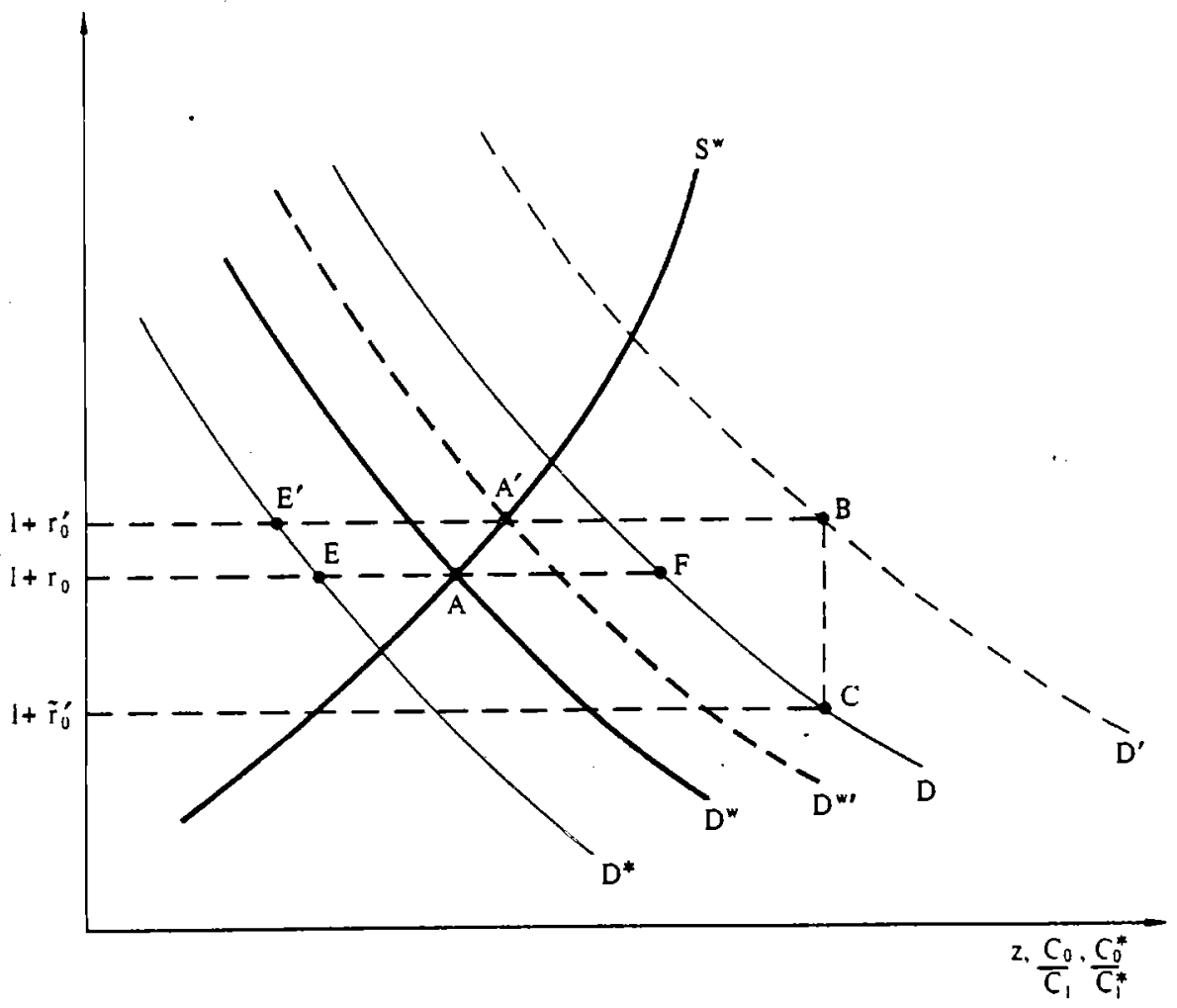


factor. This proportion is $\left(1+\tau_{c 1}\right) /\left(1+\tau_{c o}\right)$. Assoclated with the new levels of domestic demand, the new world relative demand $\left(C_{0}+C_{0}^{*}\right) /\left(C_{1}+C_{1}^{*}\right)$ also shifts to the right from $D^{W}$ to $D^{W^{\prime}}$ in Figure 2. Th1s shift reflects the substitution from future to current-period consumption in the domestic economy. I/ Furthermore, the proportional displacement of the world relative demand schedule is smaller than the corresponding displacement of the domestic relative demand schedule. $\underline{2} /$

In contrast with the effects of the tax reforms on the relative demand schedules, this reform, which does not affect the effective discount factor applicable to investment decisions, leaves the world relative supply schedule intact. The new equ1librium obtains at the

1/ Our assumption that the intial equilibrium was undistorted $1 \mathrm{mpl}$ ies that the real-income effects induced by the departure from the flat tax pattern are dominated by the substitution effect.

2) To verify this point we note that

$$
\hat{D}^{w}=\frac{C_{0}}{\left(c_{0}+C_{0}^{*}\right)} \hat{D}+\left[\frac{C_{0}}{\left(C_{0}+C_{0}^{*}\right)}-\frac{C_{1}}{\left(c_{1}+c_{1}^{*}\right)}\right] \hat{C}_{1} .
$$

Accordingly, the proportional change in the world relative demand is composed of two components. The first consists of the product of the proportional change of the domestic relative demand and a fraction (the relative share of current-period home consumption in the world consumption), and the second consists of the product of the proportional change in future-period consumption and a term measuring the difference between the relative shares of current and future-perlods home consumption in world consumption. Th1s latter bracketed term reflects the difference between the domest1c and forelgn saving propensities. If the current period trade-balance deficit arises from a relative low domestic saving propensity, then this bracketed term is positive. We also note that $\hat{C}_{1}$ negative since the change in the time profile of consumption taxes induces a substitution away from future period consumption. It follows that under such circumstances $\hat{D}^{W}\langle\hat{D}$ and, therefore, the displacement of the $D$ schedule exceeds that of the $D^{W}$ schedule. 
intersection of the (unchanged) world relative supply schedule, $\mathrm{S}^{\mathrm{W}}$, and the new world relative demand schedule, $\mathrm{D}^{W^{\prime}}$. This equilibrium is indicated by point $A^{\prime}$ in Figure 2 at which the world rate of interest rises from $r_{0}$ to $r_{0}$.

To determine the incidence of this change on the domestic effective rate of interest, we subtract from $1+r_{0}^{1}$ the distance $B C$ representing the tax-induced percentage change in the effective discount factor. This yields $1+\bar{r}_{0}^{\prime}$ in Figure 2. As is evident $\vec{r}_{0}^{\prime}$ is lower than the initial world rate $r_{0}$ since the vertical displacement of the $D^{W}$ schedule is smaller than the magnitude represented by the distance $B C$.

In view of the rise in the world rate of interest, both domestic and foreign investment fall, and the rate of growth of foreign consumption, as indicated by the move from point $E$ to point $E^{\prime}$ in Figure 2, rises. On the other hand, the fall in the domestic effective rate of interest applicable to consumption :owers the rate of growth of domestic consumption as indicated by the move from point $F$, to point $C$. Thus, this tax reform crowds out both domestic and foreign investment and results in a negative correlation between the rates of growth of domestic and foreign consumption.

The foregoing analysis assumed that the country introducing the tax reform runs an initial-period tax balance deficit. If on the other hand the initial trade account position was that of a surplus then, as implied by equations (12) and (13) the first component of the tax reform which malntalns the real equilibrium intact, results in a current-period government budget deficit and in a corresponding surplus in the future 
period. To restore the initial levels of tax revenue, the second component of the tax reform consists of a further rise in the currentperiod tax rate $\tau_{c o}$ and in a reduction of the future tax rate $\tau_{c 1}$. This change in the time profile of consumption taxes lowers the effective discount factor applicable to consumption decisions and induces an intertemporal substitution in domestic demand towards futire-period consumption. Accordingly the domestic and the world relative demand schedules shift to the left. 1' An analogous analysis to the one underlying Figure 2 shows that in that case the world rate of interest falls and the domestic effective rate of interest applicable to consumption rises. As a result, in contrast with the situation in which the initial trade-balance position was in deficit, in the presence of an initial surplus in the balance of trade the tax reform crowds in both domestic and foreign investment, lowers the rate of growth of foreign consumption while raising the growth rate of domestic consumption. This

1/ We note that as in the previous case the proportional displace ment of the $D$ schedule exceeds that of the $D^{W}$ schedule if the initialperiod trade balance surplus arises from a domestic saving propensity that is relatively higher than the foreign propensity so that $C_{1} / C_{0}$ exceeds $\left(C_{1}+C_{1}^{*}\right) /\left(C_{0}+C_{0}^{*}\right)$. This can be verified by observing that in that case

$$
\left(-\hat{D}^{w}\right)=\frac{C_{1}}{C_{1}+C_{1}^{*}}(\hat{-D})+\left(\frac{C_{1}}{C_{1}+C_{1}^{*}}-\frac{C_{0}}{C_{0}+C_{0}^{*}}\right) \hat{C}_{0} .
$$

As is evident, the proportional change in $D^{W}$ (in absolute value) is equal to a fraction times the proportional change in $D$ (in absolute value 2 plus a negative term (since $\left.C_{0}<0\right)$, so that $(-) D^{W}$ falls short of $(-D)$. 
analysis underscores the critical importance of the trade-balance position in determining the domestic and international effects of such a tax reform.

\section{Revenue-neutral conversion from consumption to income taxes}

Consider now a revenue-neutral tax reform that substitutes an income-tax system for a consumption-tax system. The consequences of this tax policy are not just the opposite to those shown in the preceeding analysis since, as will be seen, the economic mechanisms governing the effects of such a tax reform are fundamentaliy different.

As in the previous section it is convenient analytically to divide the tax reform into two components. The first consisting of the a doption of permanent income taxes (at the rate $\tau_{y}$ ) accompanied by an equiproportional reduction of consumption taxes. This component leaves the real equilibrium of the system intact. With the adoption of an income-tax system, the second component of the reform consists of further adjustments of income taxes necessary to restore revenue neutrality of the government budget in each period. The changes in the periodic tax revenue, $T_{t}$, induced by the first component of the reform are

$$
T_{0}=\tau_{y}\left(\bar{Y}_{0}-I_{0}-C_{0}\right)
$$

$$
T_{1}=\tau_{y}\left(\bar{Y}_{1}+F\left(I_{0}\right)-C_{1}\right) \text {. }
$$

As before, these changes consist of the product of the ad-valorem tax rate and the corresponding period trade-balance position. Thus, the first component of the tax reform maintains the overall solvency of the 
government but, in the presence of trade imbalances, it alters the periodic values of government tax revenue. Suppose that the domestic economy runs an inttial-period trade-balance surplus. Under such circumstances the first component of the tax reform results in an Initlal-perfod government budget surplus and in a corresponding futurem period deficit. To restore revenue neutrality the inftial-period income tax rate, ' $\tau_{y 0}$, must be lowered while the fut ure-period rate, $\tau_{y}{ }_{1}$, must be raised. These changes lower the effective discount factor relevant for investment decisions, $\alpha_{I}=\left[\left(1-\tau_{y_{1}}\right) /\left(1-\tau_{y_{0}}\right)\right] \alpha$ and, thereby discour age domestic Investment at the prevailing world discount factor. Accordingly, in terms of Figure 3 in which the initial equilibrium is described by point $A$, the tax policy displaces the domestic relative supply schedule downards, from S to S'. The proportional displacement, is equal to $\left(1-\tau_{y_{1}}\right) /\left(1-\tau_{y_{0}}\right)$ which measures the percentage change in $\alpha_{I}$. The proportional downward displacement of the world relative supply schedule is smaller than the corresponding displacement of the domestic relative supply schedule. 1 '

1/ Differentiating the domestic and world supply ratios at a given world discount factor ylelds

$$
\begin{aligned}
& \hat{S}=\left[\frac{I_{0}}{\left(\bar{Y}_{0}-I_{0}\right)}+\frac{F^{\prime}\left(I_{0}\right) I_{0}}{\left(\bar{Y}_{1}+F\left(I_{0}\right)\right)}\right]\left(-\hat{I}_{0}\right), \text { and } \\
& \hat{S}^{W}=\left[\frac{F_{0}^{\prime}\left(I_{0}\right) I_{0}}{\left(\bar{Y}_{0}-I_{0}+\bar{Y}_{0}^{*}-I_{0}^{*}\right)}+\frac{\left(\bar{Y}_{1}+F\left(I_{0}\right)+\bar{Y}_{1}+F^{*}\left(I_{0}^{*}\right)\right)}{\left(-I_{0}\right)}\right.
\end{aligned}
$$

respectively. Evidentiy the proportional change in $S$ (in absolute value) exceeds the corresponding change in $\mathrm{S}^{\mathrm{w}}$ (in absolute value). 
FIGURE 3

THE EFFECTS OF A REVENUE-NEUTRAL TAX SHIFT FROM CONSUMPTION TO INCOME TAXES WITH AN INITIAL-PERIOD DOMESTIC TRADE-BALANCE SURPLUS

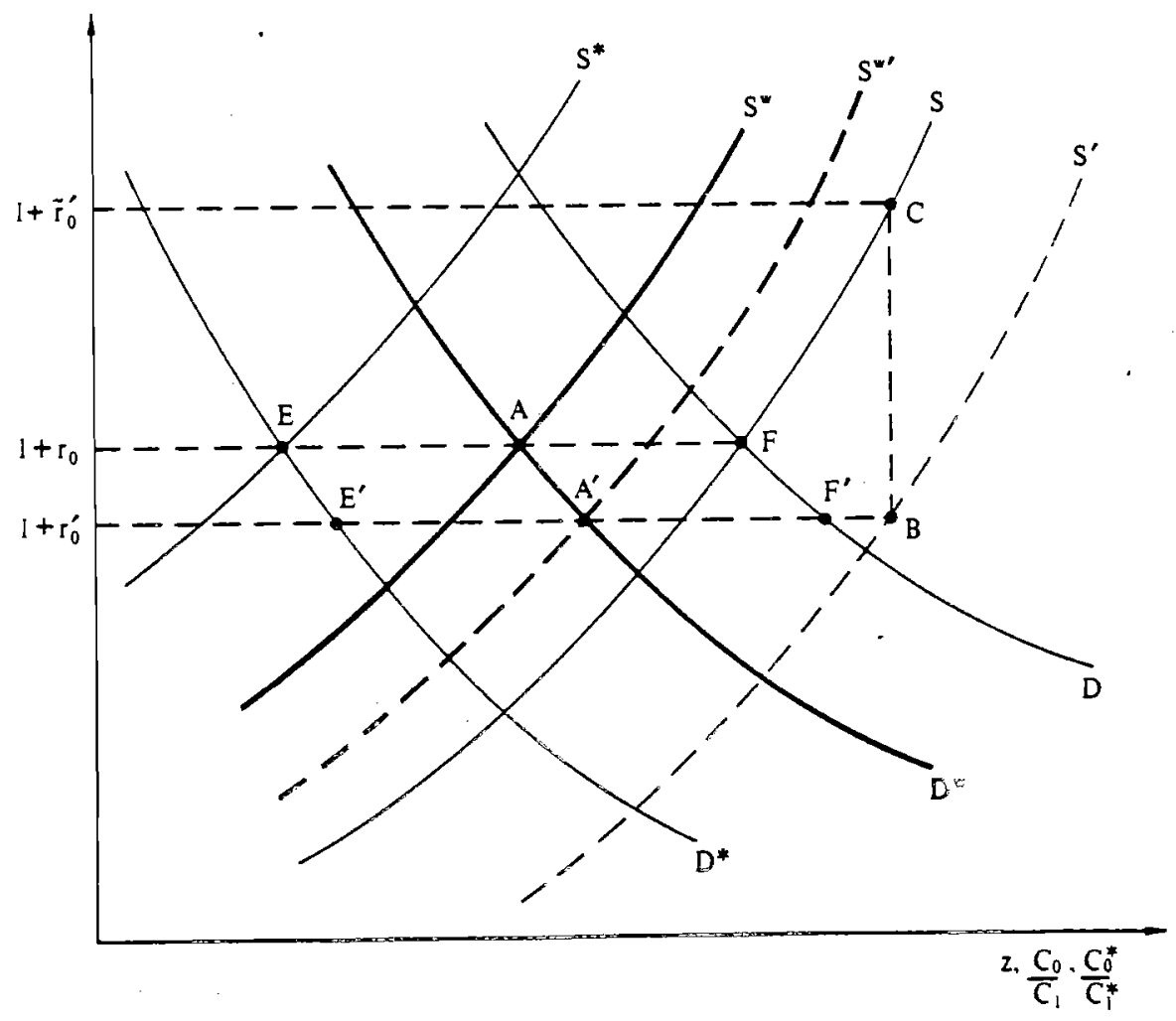


The new equilibrium obtains at the intersection of the (unchanged: world relative supply schedule, $D^{W}$, and the new world relative-supply schedule. $S^{W^{\prime}}$. This equilibrium is indicated by point $A^{\prime}$ at which the rate of interest falis, from $r_{0}$ to $r_{0}$, and (one plus) the effective interest rate applicable to domestic investment rises by the proportion $\left(1+\tilde{r}_{0}^{\prime}\right) /\left(1+r_{0}^{\prime}\right)$. This $r i s e$ is indicated by the distance BC corresponding to the vertical displacement of the domestic relative supply sohedule.

The analysis underlying Figure 3 shows that if the domestic economy runs an initial trade-balance surplus the tax reform crowds out domestic investment and crowds in foreign investment and lowers the rates of growth of domestic, forelgn and world consumption.

In contrast, if the domestic economy runs an initial-period trade deficit a similar analysis shows that the tax reform raises the world rate of interest, thereby crowding out foreign investment, while it lowers the domestic effective rate of interest applicable to investment decisions, thereby crowding in domestic investment. The reform also raises the rates of growth of consumption at home and abroad. As in the preceding subsection this analysis thus highlights the critical importance of the trade-balance position in determining the effects of the tax reform on the real equilibrium of the world economy.

The key effects of the revenue-neutral shifts between consumption and income taxes are summarized in Table 1. It is noteworthy that the effects of the tax reform on the world rate of interest and, thereby, on foreign investment and consumption growth depend only on the initialperiod trade-balance position and not on whether the tax conversion was 
Table 1. The Effects of Revenue-Neutral Shifts Between Consumption and Income Taxes

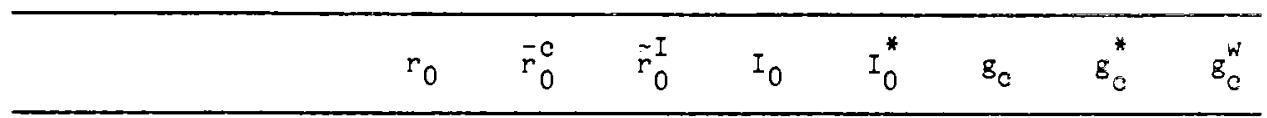

Conversion of Income for Consumption Taxes with initial-period

Trade deficit

Trade surplus

\section{Conversion of}

Consumption for

Income Taxes

with initial-period

Trade deficit

Trade surplus

Note: $r_{0}, \bar{r}_{0}^{c}$ and $\bar{r}_{0}^{I}$ denote, respectively, the world rate of interest and the domestic effective rates governing consumption and investment decisions. $I_{0}$ and $I_{0}^{*}$ denote, respectively, domestic and foreign investment, and $\mathrm{g}_{\mathrm{c}}, \mathrm{g}_{\mathrm{c}}^{*}$ and $\mathrm{g}_{\mathrm{c}}^{\mathrm{w}}$ denote, respectively, the domestic, the foreign and the world rates of growth of consumption. 
from income to consumption tax or from consumption to income tax. On the other hand the effects of the reform on the domestic economy depend on both the trade-balance psoition and the specific nature of the conversion.

\section{Foreign Direct Investment}

Throughout the preceeding analysis we have assumed that in each country capital formation arises from investment decisions of their own residents. The absence of international mobility of capital goods implies that the productivity of investment projects need not be equalized internationaliy even though the rates of return on financial investment was equalized due to the full integration of world financial capital markets. In this section we extend the formulation by allowing for direct investment abroad. This extension modifies the analysis of the implications of alternative tax policies for the international allocation of investment.

Once we allow for international mobility of productive capital, the world pool of capital is allocated internationally so as to equalize the (tax adjusted) marginal productivities of investment capital across countries. Under such clrcumstances, the world relative supply schedule, $S^{W}$, reflects the equilibrium international allocation of investment associated with the equality of the (tax adjusted) marginal productivities of investment capital across countries.

The analysis (with zero taxes) is carried out with the aid of Figure 4 which is the counterpart to Figure 1. Panel II of Figure 4 describes the domestic and foreign marginal productivities of investment 
capital, $F^{\prime}\left(I_{0}\right)$ and $F^{*}\left(I_{0}^{*}\right)_{a}$ as functions of the corresponding leyeds of investment. The negative slopes of these schedules reflect the assumption of diminishing marginal productivities. The schedule $D_{F}^{r}$ portrays the world demand for investment as a negative function of the rate of interest. This schedule is derived as the horizontal sum of the domestic and foreign marginal productivities of investment capital, $F^{\prime}\left(I_{0}\right)$ and $F^{*}\left(I_{0}^{*}\right)$. Panel III portrays the negatively sloped schedule, $J$, describing the relation between the level of world investment, $I_{0}^{W}$, and the world relative supply, $S^{W}$. This relation is

$$
\begin{aligned}
& \text { (16) } S^{W}=\frac{\bar{Y}_{0}^{W}-I_{0}^{W}}{\bar{Y}_{1}^{W}+H\left(I_{0}^{W}\right)} \text { where } \\
& \bar{Y}_{0}^{W}=\bar{Y}_{0}+\bar{Y}_{0}^{*}, \bar{Y}_{1}^{W}=\bar{Y}_{1}+\bar{Y}_{1}^{*}, I_{0}^{W}=I_{0}+I_{0}^{*}, \\
& H\left(I_{0}^{W}\right)=\operatorname{Max}_{\left\{I_{0}, I_{0}^{*}\right\}} F\left(I_{0}\right)+F^{*}\left(I_{0}^{*}\right) \text { subject to } I_{0}+I_{0}^{*}=I_{0}^{W} .
\end{aligned}
$$

Accordingly, the world relative supply equals to the ratio of the current-period world GDP net of investment to the future-period maximized value of world GDP where maximization is carried out with respect to the international allocation of world investment. The 45 degree line in Panel IV transforms this information to Panel I. Finally, the positively sloped $S^{W}$ schedule in Panel $I$ combines the negative relation between the level of world investment and the rate of interest (from Panel II) and the negative relation between the world relative supply and world investment (in Panel III). Obviously, by construction, the $S^{w}$ schedule reflects the consequences of the 
FIGURE 4

\section{WORLD EQUILIBRIUM WITH AN INTEGRATED MARKET FOR INVESTMENT CAPITAL}

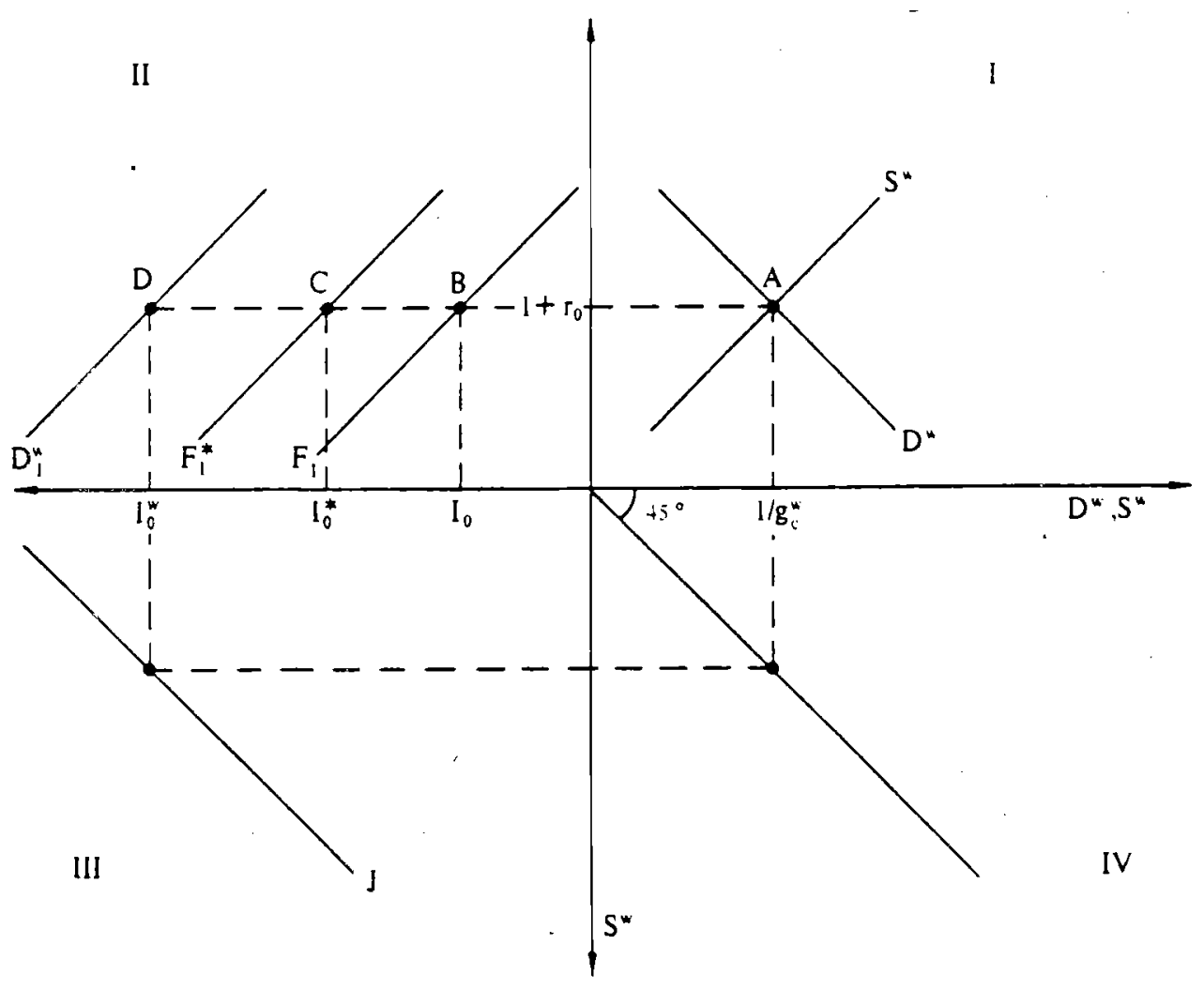


underlying assumption that the world market for investment capital is fully integrated. Analogously to the analysis in Figure 1, the downward sloping $D^{\mathrm{W}}$ schedule is the world relative demand.

The Initial equilibrium is characterized by points $A, B, C$ ard $D$ in Figure 4. Associated with this equilibrium, the world rate of interest is $r_{0}$, the rate of growth of world consumption is $g_{c}^{W}$, the levels of investment in the domestic and the foreign economies are $I_{0}$ and $I_{0}^{*}$, respectively, and their sum $1 s I_{0}^{W}$. With the integrated world market for investment capital, investment in each country can be carried out by residents of both the domestic as well as the foreign economies. Finally, the equilibrium rates of growth of domestic and foreign consumption can be read from the individual-countries' relative demand schedules (not drawn) as in Figure 1.

The introduction of taxes into the market modifies the equilibrium in a manner which depends on the specific tax treatment of direct foreign investment. A thorough analysis of this issue is beyond the scope of this paper. In what follows we sketch, however, some implications of two simple specifications of tax treatments, which span a spectrum of alternative real-world treatments.

Consider first an international tax arrangement by which investors pay taxes on their total income (1ncluding earning on foreign investment) in their country of residence while they are. exempt from foreign taxes. Under such circumstances the effective discount factors applicable to investment by domestic and foreign residents are 
(17) $\alpha_{I}=\frac{1-\tau_{y} 1}{1-\tau_{y}} \alpha, \quad \alpha_{I}^{*}=\frac{1-\tau_{y}^{*}}{1-\tau_{y 0}^{*}} \alpha$.

Since under the assumed tax treatment the location of investment does not influence the investors' tax Iiabilities, it follows that in equilibrium the international equalization of the tax-adjusted marginal productivities of investment capital also implies that the unadjusted marginal productivities are also equalized. Accordingly,

(18) $F^{\prime}\left(I_{0}\right)=F^{*}\left(I_{0}^{*}\right)$

Armed with this information consider a revenue-neutral shift from income to consumption taxes. Following a similar procedure as in the previous sections we recall that the first component of the reform, consisting of a permanent equiproportional replacement of income by consumption taxes, Ieaves the real equilibrium intact. This component of the reform alters the periodic government tax revenue by

$$
\begin{aligned}
& T_{0}=\tau_{C}\left(C_{0}-\bar{Y}_{0}-I_{H O}+I_{F O}\right) \\
& T_{1}=\tau_{C}\left(C_{1}-\left(\bar{Y}_{1}+F\left(I_{0}\right)\right)+F^{\prime}{ }^{*}\left(I_{0}^{*}\right) I_{F O}-F_{I}^{\prime}\left(I_{O}\right) I_{H O}^{*}\right.
\end{aligned}
$$

Where $I_{H O}$ and $I_{F O}$ denotes the levels of domestic residents' investment at home and abroad, respectively, and $I_{H O}^{*}$ denotes the level of foreign. residents' investment in the home country. Accordingly total investment in the home country is $I_{O}=I_{H O}+I_{H O}^{*}$ and total investment in the foreign country is $I_{0}^{*}=I_{F O}+I_{F O}^{*}$ where $I_{F O}^{*}$ denotes foreign 
residents' investment in their own country. As is evident the budgetary imbalances arising from the first component of the tax reform depends on the imbalances in the (non-interest) current account. positions. The second component of the reform, consisting of further adjustment of the consumption taxes so as to restore revenue neutrality, alters the relative demand schedule in Figure 4 in a manner identical to the one analyzed in Figune 2 of Section IV. 1 while leaving the relative supply schedule intact. Evidently, the direction of the change in the key economic variables is the same as indicated in the top panel of Table 1.

If the reform substitutes income for consumption taxes then, as before, the first component of the reform leaves the real equilibrium intact while the second component, designed to correct the budgetary imbalances through further adjustments of income taxes, alter the real equilibrium through changes in the effective discount factor governing investment by domestic residents. In analogy to the results shown in the bottom panel of Table 1, the qualitative effects of the reform on the key economic variables depend on the initial-period (non-interest) current-account position. The main difference, however, is that in the present case the levels of investment in the domestic and the foreign economies are positively correlated. This positive correlation reflects the assumed tax arrangement by which tax liabilities do not depend on the location of investment.

Consider next an international tax arrangement by which the investors' tax liabilities depend only on the location of investment and not on their country of residence. In that case the effective 
discount factors, $\alpha_{H I}$ and $\alpha_{F I}$ applicable to investment in the domestic and the foreign countries, respectively, are

$$
\alpha_{H I}=\frac{1-\tau_{y 1}}{1-\tau_{y 0}} \alpha, \quad \alpha_{F I}=\frac{1-\tau_{y 1}^{*}}{1-\tau_{y 0}^{*}} \alpha .
$$

The international equalization of the tax-adjusted marginal productivities implies that

$$
\alpha_{H I} F^{\prime}\left(I_{0}\right)=\alpha_{F I} F^{\prime *}\left(I_{0}^{*}\right) .
$$

Evidentiy, this formulation of the tax treatment does not alter the analysis of a shift between income to consumption taxes but it impacts on the analysis of the effects of a shift from consumption to income taxes. The main difference is that the levels of domestic and foreign investment are negatively correlated. This negative correlation reflects the assumed tax arrangement by which the investors' tax Ilabilities depend only on the location of investment. In this respect the results of the tax reform under this tax arrangement resemble those shown in Table 1 for the case of no direct foreign investment.

\section{Concluding Remarks}

This paper highlights the significance of open-economy considerations in the analysis of tax reforms. When the open-economy considerations are ignored then under some conditions, income and consumption taxes are known to be equivalent in the sense that the 
economic effects of each one can be replicated by the other. Obviously, under such conditions shifts between income and consumption tax systems are irrelevant. This equivalence between the two tax systems breaks down once one allows for discrepancles between national income and national spending, as permitted by international borrowing and lending. Accordingly for the open economy the tax systems are linked through another equivalence relation involving four tax systems: income tax, consumption tax, international borrowing tax and external interest-earning tax.

In this paper we analyzed the domestic and international consequences of tax reforms associated with shifts between income and consumption tax systems. Since such tax reforms involve only two of the four tax systems connected through the equivalence relationship, their effects on the economic system are not neutral. The paper identifies the key factors, mechanisms and channels through which such tax reforms exert their effect.

The principal result is that the direction of the changes in interest rates, domestic and foreign investment, growth rates of consumption and other key macroeconomic variables consequent on revenue-neutral tax reforms depends critically on the economy's current-account position. It is shown that for any given configuration of current-account imbalances the international consequences of tax reforms are independent of whether the reform replaces consumption tax for income-tax systems or vice versa. on the other hand, the implications for the domestic economy depend critically on whether the tax reform replaces a consumption-tax system 
for an income-tax system or, conversely, whether the reform replaces an income for consumption tax systems.

We cast the analysis of tax reform in a manner that sheds Iight on the domestic and international consequences of budget deficits. Specifically, an implication of our analysis is that under a consumption-tax system a budget deficit lowers the worldrate of interest while under an income-tax system the same deficit raises the world rate of interest. 1/ In addition, an appendix to the paper contains an analysis of tax shifts between an international-borrowing tax system and a consumption tax system. That analysis also underscores the key role played by the imbalances in current account in determining the effects of such a reform.

Throughout the main part of the paper we assumed that factors of production, labor and capital, are internationally immobile. Under such circumstances taxes on earnings from capital and earnings from labor operate in a similar manner in the analysis of the effects of tax reform. For that reason we did not find it necessary to distinguish between 1 abor and capital income-tax rates in the context of our analysis of the income tax system. In the penultimate section of the paper we considered the case in which investment capital is mobile internationally. Under such circumstances we needed to specify the nature of the tax treatment of direct foreign investment. In this context we considered two alternative formulations that span the broad spectrum of possible tax treatments. Our analysis demonstrates the 
robustness of the key proposition concerning the dependence of the effects of tax reforms on current-account imbalances. In addition it identifies the features of the tax treatment of direct foreign investment that are responsible for the emergence of positive or negative correlations between domestic and forelgn investment consequent as tax reform.

By highlighting the international consequences of domestic tax reforms and by identifying the channels through which the effects of such reforms are transmitted to the rest of the world, our analysis provides a clear rationale for international coordination of tax policies.

Finally, our analysis of the consequences of tax reforms focused on issues in positive economics. However, being grounded on solid microeconomic foundations, the analytical framework developed in this paper is capable of addressing also nomative issues. 1/ Accordingly, extensions of the analysis would evaluate alternative tax systems in terms of their consequent excess burdens associated with distortionary taxes as well as in terms of the inter and intra-generational distribution of welfare associated with the dynamic patterns of tax policies.

if For a recent normative analysis of excess burdens associated with tax policies in a closed-economy context see Judd (1987a, 1987b) and fol a corresponding closed-econony analysis of intergenerational distribution of welfare in a context of a life-cycle model see Summers (1981), Auerbach and Kotlikoff (1983) and Seidman (1984). 


\section{Variable Labor Supply}

In this appendix, we extend the stylized model to allow for a variable labor supply. To allow for endogenous labor supply and variable output, we modify the utility function and the production function.

Normalizing total endowment of time in each period t to unity, let the fraction of time spend on labor be $l_{t}$. Correspondingly, the fraction of time left for leisure is $1-l_{t}$. We assume that lifetime utility is a function of four "goods:" ordinary consumption $\left(\mathrm{C}_{0}, \mathrm{C}_{1}\right)$, and leisure consumption $\left(1-1_{0}, 1-1_{t}\right)$. To facilitate the exposition, suppose that the utility function is separable between ordinary consumption and leisure, and let each subutility be homothetic. These assumptions imply that the utility-maximizing ratio of consumption in the two consecutive periods depends only on the rate of interest; likewise, the utility-maximizing ratio of leisure in the two consecutive periods depends only on the ratio of wages (net of tax).

with variable labor supply it is convenient to include in the definition of lifetime spending the imputed spending on leisure.

Correspondingly, the definition of wealth includes the imputed value of labor endowment. Thus, the lifetime budget constraint is

$$
\text { (A.I) } \quad \begin{aligned}
C_{0} & +\left(1-\tau_{y 0}\right)\left(1-1_{0}\right) w_{10}+\alpha\left[C_{1}+\left(1-\tau_{y l}\right)\left(1-I_{1}\right) w_{11}\right] \\
& =\left(1-\tau_{y 0}\right) w_{10}+\left(1-\tau_{y 0}\right)\left(r_{k 0} K_{0}-I_{0}\right) \\
& +\alpha\left\{\left(1-\tau_{y 1}\right) w_{11}+\left(1-\tau_{y 1}\right) r_{k 1}\left[K_{0}+K\left(I_{0}\right)\right\}\right. \\
& -\left(1+r_{-1}\right) B_{-1}^{p}=w_{0},
\end{aligned}
$$


where ' $\tau_{y t}$ ' $w_{1 t}$, and $r_{k t}$ denote, respectlvely, the income tax, the wage rate, and the rental rate on capital in period $t(t=0,1)$, and where $K_{0}$ denotes the initial endowment of capital. As indicated in (A.1), the individual lifetime ( $f u l l$ ) income--that is, the indlvidual wealth $\left(w_{0}\right)-$ is the discounted sum of the value of time endowment (net of taxes) and of capital income (net of initial debt comitment). Capital income in the current period is the rental on existing capital, $\mathrm{r}_{\mathrm{kO}} \mathrm{K}_{\mathrm{O}}$, minus investment, $I_{0}$; correspondingly (altering somewhat our notation in the text) the stock of capital in the sebsequent period is $\mathrm{K}_{0}+\mathrm{K}\left(\mathrm{I}_{0}\right)$.

Maximizing of the utility function subject to the lifetime budget constraint yields the demand functions for ordinary consumption and for leisure in each period. These demand functions depend on the three relative prices (net wages in each of the two periods and the discount factor) and on wealth. Accordingly, the labor supply functions (which are inversely related to the lelsure demand functions) can be written as

$$
\begin{aligned}
& \text { (A.2) } 1_{0}=1_{0}\left[\left(1-\tau_{y_{0}}\right) \mathrm{w}_{10}, \alpha, \alpha\left(1-\tau_{\mathrm{y} 1}\right) \mathrm{w}_{11} ; \mathrm{w}_{0}\right], \\
& \text { (A.3) } 1_{1}=1_{1}\left[\left(1-\tau_{y_{0}}\right) \mathrm{w}_{10}, \alpha, \alpha\left(1-\tau_{\mathrm{y} 1}\right) \mathrm{w}_{11} ; \mathrm{W}_{0}\right] .
\end{aligned}
$$

The assumption that le1sure is not a Giffen good implies that a rise in the current perlod net wage raises $l_{0}$ and a rise in the (discounted value of) future net wage raises $1_{1}$. Assuming that the amounts of leisure consumed in two consecutive periods are gross substitutes implies that for a given level of wealth, a current tax cut lowers future labor supply while a future tax cut lowers current labor supply. 
In each period, the level of outputs $Y_{O}$ and $Y_{1}$ depends on labor and capital inputs. In order to simplify the exposition, we assume linear production functions. Thus, let

$$
\begin{aligned}
& \text { (A. 4) } \quad Y_{0}=a_{0} I_{0}+b_{0} K_{0}, \\
& \text { (A.5) } \quad Y_{1}=a_{1} I_{1}+b_{1}\left[K_{0}+K\left(I_{0}\right)\right] .
\end{aligned}
$$

The assumption that factor markets are competitive implies that in equilibrium the wage rates and the rental rate equal the corresponding marginal productivities of labor and capital, respectively. Thus

$$
\text { (A.6) } \quad w_{10}=a_{0}, w_{11}=a_{1}, r_{k 0}=b_{0}, r_{k 1}=b_{1} \text {. }
$$

As usual, profit-maximizing investment implies equality between the marginal cost of capital $\left(1+r_{0}\right)$ and the marginal return on the investment, which is the product of the marginal product of investment in capital formation (net of taxes) and the discounted sum of the rental rates on capital. Hence, in the present two-period model, profit maximization requires that

$$
\text { (A. 7) } \frac{\left(1-\tau_{y 1}\right)}{\left(1-\tau_{y_{0}}\right)} r_{k 1} K^{\prime}\left(I_{0}\right)=1+r_{0} \text {. }
$$

In order to close the model, we note that the present-value budget constraint of the government is

$$
G_{0}+\alpha G_{1}=\tau_{y 0}\left(w_{1} I_{0}+r_{k 0} K_{0}-I_{0}\right)+\alpha \tau_{y}\left(w_{11} I_{1}+r_{k 1}\left(K_{0}+K\left(I_{0}\right)\right)-\left(1+r_{-1}\right) B_{-1}^{g} \cdot\right.
$$

Combining the private sector lifetime constraint (A.1) with the government present-value constraint (A.8), and making use of the supply-side 
equations (A.4)-(A.5), yields the econony's consolidated budget constraint in which the discounted sum of consumption equals $V_{0}$, where

$$
\begin{aligned}
C_{0}+\alpha C_{1} & =\left(a_{0} I_{0}+b_{0} K_{0}-G_{0}-I_{0}\right) \\
& +\alpha\left\{a_{1} I_{1}+b_{1}\left[K_{0}+K\left(I_{0}\right)\right]-G_{1}\right\}-\left(1+r_{-1}\right) B_{-1} .
\end{aligned}
$$

A key property of the specification of this constraint is that it is evaluated by using undistorted prices. Obviously, the wages that appear as arguments in the consumption and leisure demand (labor supply) functions, $C_{0}, C_{1}, 1_{0}$, and $l_{1}$ are the after-tax wages.

To analyze the equilibrium of the system, we assume that the foreign economy has a similar structure of production, consumption, and taxes. The initial equilibrium of the system is described by point $A$ in Figure 2. As before, the downwards sloping schedules $D$ and $D^{*}$ denote the domestic and foreign relative demands for (ordinary goods) consumption in the two periods, and the schedule $D^{W}$ is the weighted average of the domestic and foreign relative demands. The negative slopes of the schedules reflect the intertemporal substitution arising from changes in the rate of interest. The positively sloped schedule, $s^{W}$, reflects the response of $z$ to the rate of interest, where, as before, $z$ measures the ratio of world GDP net of investment and government spending in the two consecutive periods.

That is

(A. 10)

$$
z=\frac{\left(a_{0} I_{0}+b_{0} K_{0}-I_{0}\right)+\left(a_{0}^{*} I_{0}^{*}+b_{0} K_{0}^{*}-I_{0}^{*}\right)}{a_{1} I_{1}+b_{1}\left[K_{0}+K\left(I_{0}\right)\right]+a_{1}^{*} I_{1}^{*}+b_{1}^{*}\left[K_{0}^{*}+K^{*}\left(I_{0}^{*}\right)\right]}
$$


The $S^{W}$ schedule is drawn with a positive slope for convenience. In fact, changes in the rate of interest affect the intertemporal prices of leisure and of ordinary goods as well as wealth. These changes may alter the supply of labor in a way that more than of fsets the effect of the induced changes in investment on $z$. In that case, the $\mathrm{s}^{\mathrm{w}}$ schedule is negatively sloped, but as long as it is steeper than the world relative demand schedule, our interest rate analysis remains intact.

A revenue-neutral tax reform that substitutes an income-tax system for a consumption-tax system exerts effects that are similar to those in Section IV. 2 in the paper. As in that case the adjustments of income tax rates necessary to restore revenue neutrality in each period (which depend on the economy's trade-balance position) alter the time profile of income taxes. As indicated by equations (A.1)-(A.2), the change in the time profile of income taxes alter the periodic labor supply and, thereby, alter the relative output supply function $\mathrm{S}^{\mathrm{W}}$.

The change in the income-tax profile has no effect on the relativedemand schedules since by the assumed separability and homotheticity they only depend on the effective interest rate. The shifts in the relative-supply schedules induced by the tax reform are governed by the effect of the tax reform on investment as well as on the amount of work. Since both operate in the same direction, the essence of the analysis in Section IV. 2 with respect to the world rate of interest remains unchanged.

The opposite conversion from income to consumption taxes involves changes in the time profile of consumption taxes (necessary to restore revenue neutrality) and thereby result in relative demand shifts simllar 
to those analyzed in Section IV.1. The diagrammatic analysis of Figure 2 must, however, be somewhat modified to allow for the change in the relative supply schedules induced by changes in labor supply consequent on the altered effective discount factor applicable to consumption decisions involving ordinary goods as well as leisure. Finally we note that with variable labor supply (though immobile internationally) and with international mobility of investment capital, the analysis of income taxes must distinguish between the different effects of taxes on labor income and on income from capital. 


\section{Income Tax with Delayed Expensing of Investment}

In the main text we have assumed that the income tax system is a cash-flow system with full expensing of investment. In this appendix we modify the specification of the income tax system and consider the other extreme in which current period investment is not expensed but the allowance for depreciation of capital is delayed to the final period. This modification alters the periodic budget constraints (1) - (4). To illustrate, consider the case in which the only two taxes are consumption and income taxes. Under such circumstances the private sector budget constraints are

$(A .11) \quad\left(1+\tau_{C O}\right) C_{0}=\left(1-\tau_{y o}\right) \bar{Y}_{0}-I_{0}-r_{-1} B_{-1}^{P}+\left(B_{0}^{P}-B_{-1}^{P}\right)$

$(A .12) \quad\left(1+\tau_{c 1}\right) C_{1}=\left(1-\tau_{y}\right)\left(\bar{Y}_{1}+F\left(I_{0}\right)\right)+\tau_{y 1} I_{0}-\left(1+r_{0}\right) B_{0}^{p}$

and the corresponding consolidated life-time budget constraint is

(A.13) $\quad C_{0}+\alpha_{c} c_{1}=\frac{1+r_{0}^{-\tau} y 1}{\left(1+r_{0}\right)\left(1+\tau c_{0}\right)}\left[\alpha_{I} F\left(I_{0}\right)-I_{0}\right]$

$$
+\frac{1-\tau_{\text {yo }}}{1+\tau_{C O}}\left[\bar{Y}_{0}+\alpha_{L} \bar{Y}_{1}\right]-\frac{1+r_{-1}}{1+\tau_{c o}} B_{-1}^{p}
$$

where

(A.14)

$$
\begin{aligned}
& \alpha_{c}=\frac{1+\tau_{c l}}{1+\tau_{c 0}} \alpha, \alpha_{I}=\frac{1-\tau_{y} 1}{1+r_{0}-\tau_{y} 1} \\
& \alpha_{L}=\frac{1-\tau_{y} 1}{1-\tau_{y 0}} \alpha, \text {, and } \alpha=\frac{1}{1+r_{0}} .
\end{aligned}
$$


In equations (A.13) and (A.14) $\alpha_{C}, \alpha_{I}$ and $\alpha_{L}$ are the effective discount factors applicable to consumption, investment, and labor-supply decisions. For simplicity in this appendix the supply of zabor, however, is assumed to be fixed.

As is evident the effective discount factor $\alpha_{I}$ is not influenced by the current-period income tax rate ' ${ }_{\text {yo }}$; this reflects the assumption that investment outlays are not expensed during the current period. Since $\alpha_{I}$ depends positively on $\tau_{y}$, it follows that a shift from income tax to consumption tax (that is, a reduction in $\tau_{y}$ ) raises the effective discount factor $\alpha_{I}$ and, thereby, encourages investment. Diagrammatically, this change induces a leftward shift in the domestic and the world relative supply schedules. In and of itself this induces a rise in the world rate of interest. Using the diagrammatic apparatus the reader can infer the changes in all other variables. Finally we note that in contrast with the cash-flow income tax with full expensing of investment the qualitative results in the present case do not depend on the trade-balance position as Iong as the supply of labor is fixed. With variable labor supply (analyzed in Appendix I) the current period income tax rate $\tau_{\text {yo }}$ influences the relative supply function through its influence on the effective discount factor $\alpha_{L}$. In that case the necessary changes in the income tax rates associated with the adoption of an income-tax system reflect as before the trade-balance position. 


\section{Tax on International Borrowing}

In this appendix we examine some implications of a reform involving a conversion from a consumption-tax system to an international borrowing tax system. The procedure that we adopt in the analysis differs somewhat from the one adopted in the analysis of conversions between income and consumption-tax systems. In analyzing these conversions we have seen that the first component of the tax reform, consisting of equi-proportional permanent changes in the tax rates is neutral with respect to the real equilibrium. The tax-equivalence relation discussed in the text, implies that an international borrowing-tax system contains elements of both income and consumption-tax systems. It follows that an equi-proportional permanent conversion of consumption and internationalborrowing taxes must alter the real equilibrium. Therefore, it is not useful to apply here the same decomposition of the reform into the two components. Instead, we consider a shift from a consumption tax system to an international borrowing tax-system which maintains the flat time pattern of consumption taxes while ensuring revenue neutrality by periodic adjustments in the international borrowing tax rates. In that case, the government budget constraints (equations (3) and (4) of the text) imply that
(A. 15)
$\tau_{C} C_{0}+\tau_{b O} B_{0}^{p}=0$
(A.16)$$
\tau_{c} C_{1}-\tau_{b 1} B_{0}^{p}=0
$$

Equations (A.15)-(A.16) imply that if the domestic economy runs an initial period trade balance deficit, that is if ${ }_{B}^{p}$ is positive, then 
the revenue-neutral flat reduction in the consumption tax rate, 'c' necessitates a rise in $\tau_{b 0}$ (resulting in a tax on international borrowing) and a fall in $\tau_{b l}$ (resulting in a subsidy on international borrowing).

These changes in the periodic international borrowing taxes alter the flatness of this tax and lower the values of both $\alpha_{c}$ and $\alpha_{I}$ (the effective discount factors applicable to domestic consumption and investment decisions). This rise in the effective domestic rate of interest discourages domestic current-period consumption and investment and induces a leftwards shift of the domestic relative demand schedule and a rightwards shift of the domestic relative supply schedule. The dowmwards displacement of both schedules equal the proportional fall in the discount factors, $\left[\left(1-\tau_{b 0}\right) /\left(1+r_{0}-\tau_{b l}\right)\right]\left(1+r_{0}\right)$. These displacements are necessary in order to maintain the effective domestic rates of interest unchanged for any given level of relative demand and supply. Figure A-1 illustrates the effects of this tax reform for the case in which the domestic country runs an initial-period trade-balance deficit. The new world relative demand also shifts to the left from $D^{W}$ to $D^{W^{\prime}}$, and its proportional displacement is smaller than the corresponding displacement of the $D$ schedule.

The world relative-supply schedule shifts to the right from $S^{W}$ to $\mathrm{S}^{\mathrm{W}^{\prime}}$ and its proportional displacement is also smaller than the corresponding displacement of the $S$ schedule. Hence, the new equilibrium obtains at point $A^{\prime}$ at which the world rate of interest falls from $r_{0}$ to $r_{0}^{\prime}$. This lower world rate of interest stimulates investment in the foreign country. 
To determine the incidence of the change in the tax on the equiIibrium value of the domestic effective rate of interest, we add to the new equilibrium value $1+r_{0}^{\prime}$, the tax-induced rise in the effective interest rate. Diagrammatically, this addition is indicated by the distance $B^{\prime} E$ in Figure $A-1$, indicating the vertical displacement of the domestic relative-demand schedule. As seen, in the new équilibrium, the domestic effective rate of interest rises to $\tilde{r}_{0}^{\prime}$, and hence, the new equilibrium is associated with lower domestic investment. We thus conclude that with an initial-period trade balance deficit, this tax reform results in a negative correlation between domestic and foreign investment.

The fall in the world rate of interest lowers the equilibrium growth rate of foreign consumption (as indicated by the move from point $C$ to point $\left.C^{\prime}\right)$. At the same time, the rise in the effective domestic effective rate of interest raises the equilibrium growth rate of domestic consumption (as indicated by the move from point $B$ to $B^{\prime}$ ). Thus, in contrast with the case of the shift from consumption to incometax systems, the present case results in a negative correlation between the growth rates of domestic and fore:gn consumption.

The effect of the tax shift on the growth rate of world consumption depends on the assumed initial-period trade-balance position which in turn determines the relative vertical displacements of the world relative-demand and relative-supply schedules. Recalling that the extent of these shifts reflect the initial-period trade-balance position, it follows (using similar arguments as in section IV of the text) that if the domestic country runs an initial-period trade-balance deficit, then the verical displacement of $S^{W}$ exceeds that of $D^{W}$ (in absolute 
FIGURE A-I

THE EFFECT OF A REVENUE-NEUTRAL TAX SHIFT FROM INTERNATIONAL BORROWING TAXES TO CONSUMPTION TAXES WITH AN INITIAL-PERIOD TRADE-BALANCE DEFICIT

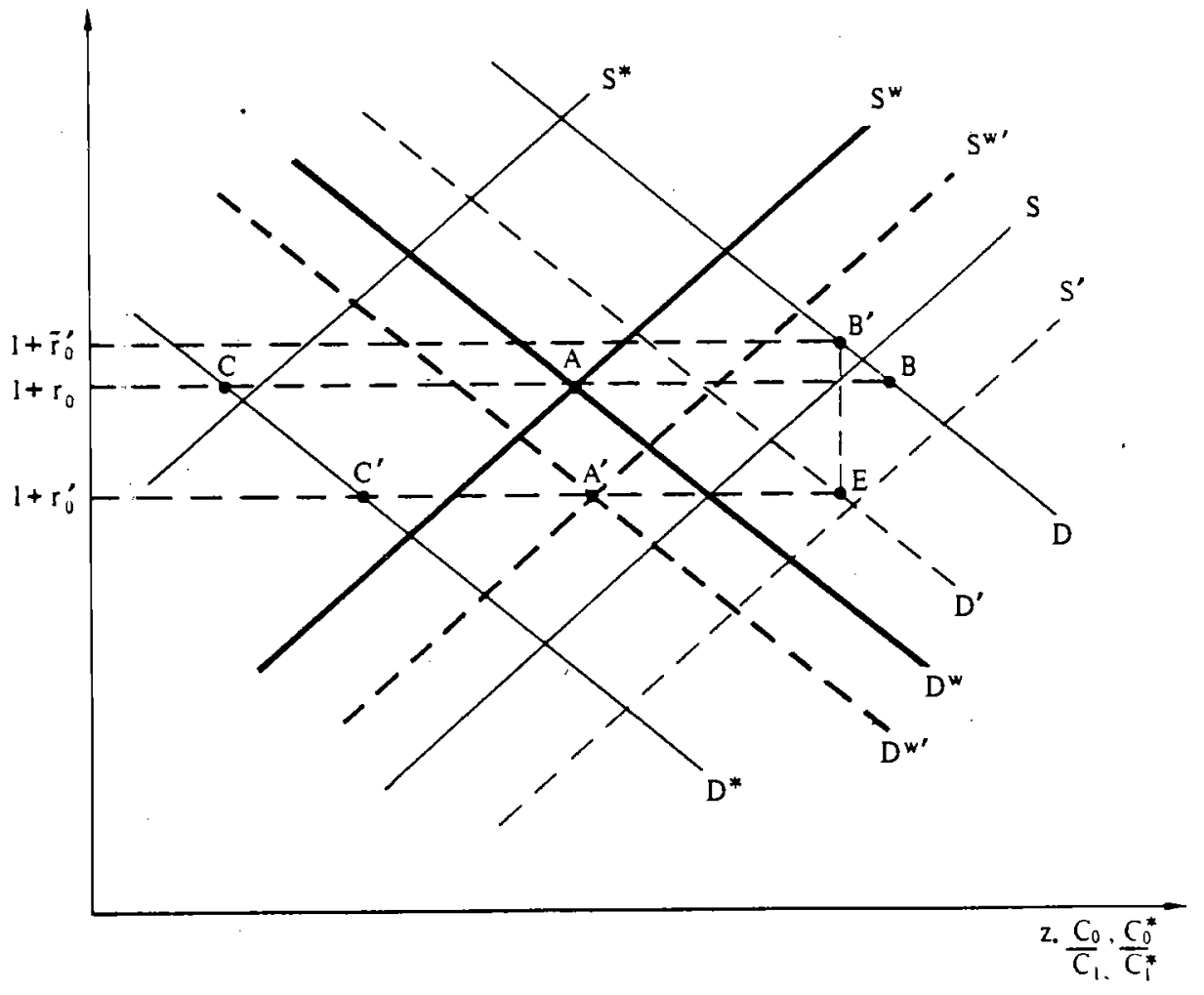


value). Consequently, the new equilibrium point $A^{\prime}$ must lie to the right of point A. Hence, the growth rate of world consumption falls.

Up to this point, we have assumed an initial-period domestic tradebalance deficit. If on the other hand the domestic economy runs an initial period trade-balance surplus then its initial-period borrowing, ${ }_{B}^{p}$, is negative and as is evident from equations (A.15)-(A.16), the revenue-neutral tax shift necessitates a fall in the initial-period international borrowing tax, ' $b 0$ ', and a fall in the subsequent-period tax, $\tau_{b l}$. These changes raise the effective domestic discount factors $\alpha_{C}$ and $\alpha_{I}$ and induce corresponding equi-proportional downward displacements of the domestic relative demand and supply schedules. It can be verified that all the qualitative results obtained for the case of an initial-period trade-balance deficit are reversed except for the effect on the growth rate of world consumption. Since with an initial period trade-balance surplus the vertical upward displacement of the world relative demand schedule exceeds the corresponding displacement of the world relative supply. Accordirgly, also in this case the new equilibrium point A' lies to the right of A so that the growth rate of world consumption falls.

Our formulation of the tax structure has also allowed for taxes on interest earnings. Inspection of the periodic government budget constraints $(3)-(4)$ and the consolidated private-sector budget constraint (5) reveals that the economic effects of that tax on the saving-investment balance are qualitatively similar to those of the international borrowing tax. For this reason, we do not carry out a detailed analysis of a revenue-neutral tax reform involving interest earning taxes. 


\section{References}

Auerbach, Alan J. and Lawrence J. Kotlikoff, "National Savings, Economic Welfare, and the Structure of Taxation," In Behavioral Simulation Methods in Tax Pollcy Analysis, edited by Martin Feldstein. Chicago: Unversity of Chicago Press, 1983. , Dynamic Fiscal Policy, New York: Cambridge University Press, $19 \overline{87}$.

Boskin, Michael J., Federal Tax Reform: Myths and Realities, Institute for Contemporary Studies, 1978.

Bradford, David F., Blueprints for Basic Tax Reform, second edition, revised, Tax Analysts (Arlington, Virginia, 1984). - Untangling the Income Tax, Harvard University Press, Cambridge, $19 \overline{86 .}$

Brock, William and Stephen Turnovsky, "The Analysis of Macroeconomic Policies in a Perfect Foresight Equilibrium," International Economic Review, 84, (February, 1981): 179-209.

Frenkel, Jacob A., and Razin, Assaf, "Deficits with Distortionary Taxes: International Dimensions," NBER Working Paper No. 2080 (November 1986). - Fiscal Policies and the World Economy, MIT Press, $19 \overline{87 .}$

Hall, Robert E., and Alvin Rabushka, Flat Tax, Simple Tax, New York: McGraw Hill (1983).

Judd, Kenneth L., (1987a) "A Dynamic Theory of Fact or Taxation," American Economic Review, 77, No. 2 (May, 1987): 42-48.

, (1987b) "The Welfare Cost of Factor Taxation in a PerfectForesight Model," Journal of Political Economy, 95, No. 4 (August 1987): $675-709$.

King, Mervyn, "Prospects for Tax Reform in 1988," Discussion Paper No. 0010, LSE Financial Markets Group Discussion Paper Series, LSE, London (1987).

Pechman, Joseph A. (ed), Comparative Tax Systems: Europe, Canada and Japan, Tax Analysts, Arlington, Virginia (1987).

Seidman, Lawrence S., "Conversion to a Consumption Tax: The Transition in a Life-Cycle Growth Model," 92, No. 2 (April 1984): 247-267. 
Summers, Lawrence H., "Capital Taxation and Accumulation in a Life-Cycle Growth Model," Amerlcan Economic Review, 71 (September 1981): 53344.

Tanzi, Vito, "Tax Reform in Industrial Countries and the Impact of the U.S. Tax Reform Act of 1986" IMF Working Paper Series No. 87/61, September 1987. 